\title{
Effect of a short dry period on milk yield and content, colostrum quality, fertility, and metabolic status of Holstein cows
}

\author{
E. Shoshani, ${ }^{* 1,2}$ S. Rozen, ${ }^{\star}$ and J. J. Doekes† \\ *Extension Service, Ministry of Agriculture and Rural Development, Beit Dagan 50250, Israel \\ †"Hachaklait," Bareket St. 20, Industrial area, Caesaria 38900, Israel
}

\begin{abstract}
We evaluated the effect of shortening the dry period (DP) on milk and energy-corrected milk (ECM) yields, milk components, colostrum quality, metabolic status, and reproductive parameters. Primiparous $(\mathrm{n}=372)$ and multiparous $(\mathrm{n}=400)$ Israeli Holstein cows from 5 commercial dairy herds were subjected to a $60-\mathrm{d}$ or 40-d DP. Cows within each herd were paired according to milk production, age, days in milk, and expected calving. Analysis of the data from all cows, irrespective of age, revealed significant differences in milk and ECM yields that favored the 60 -d DP, with a prominent effect in 2 of 5 examined herds. In primiparous cows, milk and ECM yields were similar between groups in 4 of 5 farms. In multiparous cows undergoing a 60 -d (vs. 40-d) DP, milk and ECM yields were higher in 3 herds. These differences could not be explained by milk and ECM yields in cows diagnosed with metritis, ketosis, and mastitis (defined by a somatic cell count threshold of $250,000 \mathrm{cell} / \mathrm{mL}$ ), distribution of infected and noninfected cows, or new infections during DP and after calving. Including the milk and ECM yields from an average of $19.55 \mathrm{~d}$ from the previous lactation revealed higher milk and ECM yields for 40-d (vs. 60-d) DP cows in all herds. Analyzing 2 consecutive lactations revealed similar milk and ECM yields between groups in 4 out of 5 herds. In 1 herd, yields were higher in the 40-d compared with the 60-d DP group. One week after calving, the nonesterified fatty acid concentrations of 40-d DP cows were significantly lower than those of 60-d DP cows, indicating better postpartum energy balance. Colostrum quality, measured as IgG concentration, did not differ between the 2 DP groups. Cows assigned to 40-d DP had better reproductive performance, as reflected by fewer days to first insemination, a lower proportion with $>90 \mathrm{~d}$ to first insemination, and fewer days to pregnancy. With respect to primiparous cows, a
\end{abstract}

Received November 19, 2013.

Accepted February 5, 2014.

${ }^{1}$ Retired.

${ }^{2}$ Corresponding author: ezra.shoshani@gmail.com short DP increased conception rate after first artificial insemination and decreased the proportion of nonpregnant cows after $150 \mathrm{~d}$ in milk. In light of these findings, we suggest that a short DP be applied for its economic and physiological benefits. This is highly relevant to dairy herds located in regions such as Israel, Spain, and Florida that suffer from reduced milk production during the hot season.

Key words: short dry period, production, fertility, colostrum, metabolic status

\section{INTRODUCTION}

The dry period (DP) between 2 subsequent lactations is highly important as it eliminates reductions in milk yield throughout the subsequent lactation (Smith et al., 1966; Rémond et al., 1992, 1997; Annen et al., 2007). Duration of the DP has been reevaluated in the last few decades. Whereas $60 \mathrm{~d}$ is the most commonly used DP duration (Sørensen and Enevoldsen, 1991; Makuza and McDaniel, 1996; Knight, 1998), shorter DP lengths have been shown to increase milk production in the subsequent lactation, and reduce the risk of mastitis due to lower milk yield at DP onset (Bernier-Dodier et al., 2011). A short DP also decreases the number of changes in diet, which in turn might decrease the incidence of postpartum metabolic disorders (BernierDodier et al., 2011).

Several studies have examined DP length; however, their findings were not clear-cut. In one study, a short DP of $28 \mathrm{~d}$ did not have any deleterious effect on milk yield in the subsequent lactation (Annen et al., 2003), whereas others have reported contradictory results (Rastani et al., 2005). Gulay et al. (2003) did not find any difference in milk yield, for 21 wk after calving, of multiparous cows subjected to a $30-\mathrm{d}$ or $60-\mathrm{d}$ DP. Collier et al. (2012) reported that a 30-d DP reduces milk yield in primiparous cows in their second lactation. Recently, Bernier-Dodier et al. (2011) reported that a 32-d DP decreases milk yield for 20 wk postpartum. Pezeshki et al. (2007) and Santschi et al. (2011a) compared 35-d and 56-d DP and found that the shorter DP decreases milk yield in primiparous but not multiparous 
cows. However, Kuhn et al. (2006) suggested that the optimum DP length to maximize production depends on parity, suggesting a DP of 40 to $45 \mathrm{~d}$ for first and second lactations and a DP of 55 to $65 \mathrm{~d}$ after second and third lactations. They further suggested that DP of $<30 \mathrm{~d}$ and $>70 \mathrm{~d}$ should be avoided.

Nutritional regimen might alter the effect of DP duration on subsequent lactation. Dirksen et al. (1985) suggested that using 2 different diets during the $60-\mathrm{d}$ DP (a low-energy diet from 60 to $30 \mathrm{~d}$ before calving and a moderate-energy diet from $-30 \mathrm{~d}$ to parturition) does not allow optimal adjustment of the ruminal flora to the postpartum diet. In the last week of pregnancy, a rapid decrease in DMI occurs (Bertics et al., 1992), suggesting that when a short DP is applied, cows will not have sufficient time for appropriate ruminal flora development for the next lactation. Rastani et al. (2005) found that postpartum negative energy balance is more pronounced in cows subjected to a 56 -d versus $28-\mathrm{d}$ DP, probably due to higher DMI in the latter. Negative postpartum energy balance increases the risk of calving diseases such as ketosis, retained placenta, displaced abomasum, and metritis (Grummer and Rastani, 2004). Santschi et al. (2011b) reported that a short DP (35 d) combined with the feeding of a precalving ration for the whole period is correlated with decreased incidence of ketosis but increased incidence of retained placenta in adults, although the reason for this finding was not clear.

Given the association between postpartum energy balance and timing of first postpartum ovulation (Butler et al., 1981; Canfield et al., 1990), a short DP (28 d) might accelerate the time of first ovulation and return to cyclicity (Thatcher and Wilcox, 1973; Darwash et al., 1997) if only 1 high-energy diet is supplied (Gümen et al., 2005; Watters et al., 2009). In support of this, a short DP during which 2 rations were applied increased days open postpartum (Pezeshki et al., 2007). Dry period length might affect the quality of colostrum, in terms of IgG concentrations, which is essential for disease prevention in calves and hence their development (Collier et al., 2012). Omitting the DP entirely may reduce the IgG concentrations in colostrum, but shortening the DP for at least 4 wk had no effect on colostrogenesis in terms of changes in colostrum cell and fluid composition (Annen et al., 2004; Rastani et al., 2005; Watters et al., 2008).

Most planned DP experiments have been conducted with a small number of cows (Gümen et al., 2005; Rastani et al., 2005; Pezeshki et al., 2007). Moreover, most studies exploring DP length have been retrospective analyses (Bachman and Schairer, 2003). Results obtained using the latter approach are biased in favor of a $60-\mathrm{d}$ DP due to inappropriate nutrition before calving in the case of a short, unplanned DP.

The objective of the present study was to compare the effects of long (60 d) versus short (40 d) DP on primiparous and multiparous cows in large commercial dairy herds. The examined outcomes were milk yield and components and relationships between DP length, BCS changes, milk production, metabolic disorders postpartum, colostrum quality, and reproductive performance.

\section{MATERIALS AND METHODS}

\section{Cows and Experimental Layout}

The experiment was conducted over 3 consecutive years in 5 large commercial herds with 300 to 1,000 cows each. Cows were housed in loose-housing barns (bedded area $\sim 20 \mathrm{~m}^{2} / \mathrm{cow}$ ) in all herds. During the summer, all cows were cooled in the milking-parlor holding yards during and between milking and along the feeding lanes after milking. Primiparous and multiparous cows in mo 6 to 7 of pregnancy were paired within herd according to expected 305-d ECM yield, evaluated for age, DIM, and days in pregnancy, and randomly assigned to the 40-d or 60-d DP group. Actual accumulated 305d ECM yield did not differ between the experimental groups $(11,681 \mathrm{~kg}$ for $40-\mathrm{d} \mathrm{DP}$ and $11,720 \mathrm{~kg}$ for $60-\mathrm{d}$ $\mathrm{DP}, \mathrm{SEM}=80 ; P>0.05$ ) or within each farm (Table 1). Originally, 820 cows were paired for the experiment. Pairs in which 1 cow had a DP less than $25 \mathrm{~d}$ or left the herd less than 5 mo in lactation postpartum were excluded from the analysis. The reasons for excluding cows from the experiment were mastitis and abortions. Several pairs were also excluded due to incorrect dry period. The final analysis was carried out on 372 primiparous and 400 multiparous cows (Table 1).

Cows were dried off as generally practiced in Israel. Briefly, after the last milking, teats were dipped in a $0.5 \%$ iodine solution and wiped using individual towels. Teat ends were then swabbed with sponges soaked in $70 \%$ alcohol, and antibiotic (Nafpenzal DC N8 ${ }^{\mathrm{R}}$, Intervet International, Boxmeer, the Netherlands) was applied by intramammary infusion, and dipped again in $0.5 \%$ iodine solution; cows were then transferred to the dry cow group.

Feeding regimen on all farms was based on a TMR. For the 60-d DP group, nutrition was based on 2 rations. The first contained $12 \% \mathrm{CP}$ and $1.40 \mathrm{Mcal}$ of $\mathrm{NE}_{\mathrm{L}} / \mathrm{kg}$ of $\mathrm{DM}$ and $75 \%$ roughage and was fed from 60 to $21 \mathrm{~d}$ before expected calving $(\mathrm{d}=0)$. From $\mathrm{d}-21$ until calving, cows were fed a close-up ration containing $14.5 \% \mathrm{CP}, 1.55 \mathrm{Mcal}$ of $\mathrm{NE}_{\mathrm{L}} / \mathrm{kg}$ of $\mathrm{DM}$ and $60 \%$ rough- 
Table 1. Milk yield (kg; 305-d) of preceding lactation and number of cows per experimental dry period (DP) group ${ }^{1}$ in each of the 5 herds

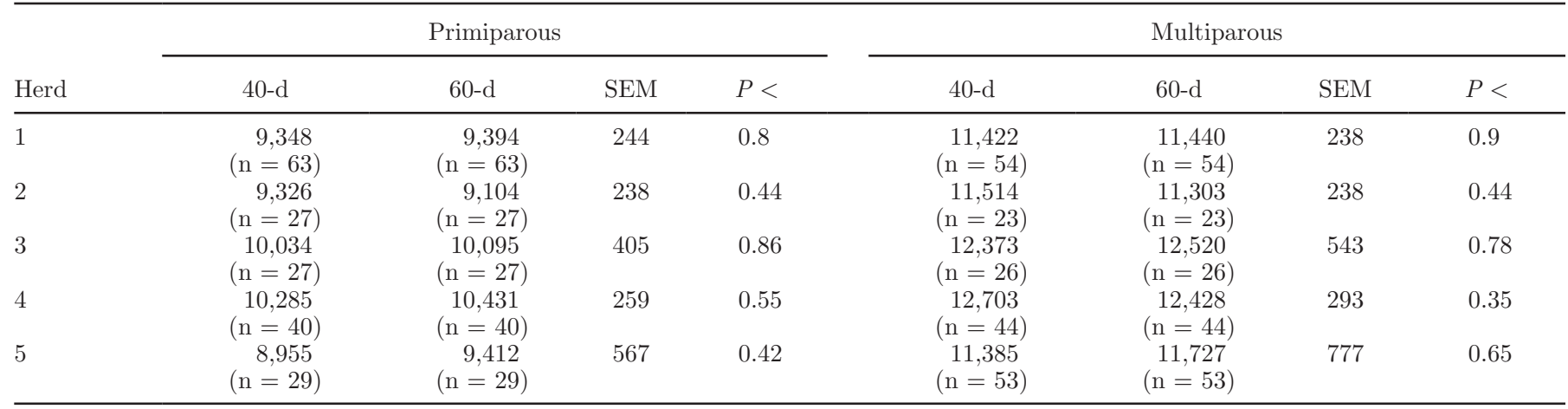

${ }^{1} 40-\mathrm{d}=$ short DP (40 d dry); 60-d = conventional DP (60 d dry).

age. The latter ration was used for the entire period in the 40-d DP groups. The main roughage sources used for both rations on all the farms were wheat hay and wheat silage. The rations were formulated to meet $\mathrm{Na}-$ tional Research Council recommendations (NRC, 2001) for vitamins $\mathrm{A}, \mathrm{D}$, and $\mathrm{E}$. The contents of calcium and phosphorus in DP rations were 0.39 and $0.32 \%$, respectively.

\section{Milk Production and Composition}

Milking was performed 3 times daily. Milk yield was recorded at milking by electronic milk meters (Zacham Afikim, Kibbutz Afikim, Israel). Milk samples were collected monthly and analyzed at the Israel Cattle Breeders Association laboratory (ICBA, Caesaria, Israel) for fat, protein, lactose contents, and SCC. Monthly milk yield was calculated and recorded in the national herd data book. In addition, ECM yield was calculated according to the formula $\mathrm{ECM}=0.1 \times$ milk $(\mathrm{kg})+$ $20.2092 \times$ protein $(\mathrm{kg})+7.65 \times$ fat $(\mathrm{kg})$.

\section{BCS}

Body condition score was measured on a 5-point scale (Ferguson et al., 1994) during wk 1 of the DP, $1 \mathrm{wk}$ postpartum, and at peak lactation (6 to $7 \mathrm{wk}$ ). Cows were classified into 3 categories: fat (BCS >3.25), normal $(2.75<\mathrm{BCS} \leq 3.25)$, and thin $(\mathrm{BCS} \leq 2.75)$, according to their BCS in wk 1 of the DP.

The effect of changes in BCS during the DP on postpartum performance was estimated by the difference in BCS between wk 1 of the DP (-1-wk_DP) and 1 wk postpartum (+1-wk). Three categories were calculated: (a) cows that had gained body-fat tissue during the dry period (+1); (b) cows in which BCS had not changed $(0)$; and (c) cows that had lost fat tissue during this period $(-1)$.

\section{Plasma NEFA Analysis}

Plasma NEFA concentrations were determined with a Wako NEFA C Test Kit (Wako Chemicals GmbH, Neuss, Germany) according to Zachut et al. (2010). Enzymatic reactions with acyl-CoA-synthetase, acylCoA-oxidase, and peroxidase generated UV emissions determined at $550 \mathrm{~nm}$ by an optical density reader calibrated at known NEFA concentrations. The inter- and intraassay coefficients of variation of NEFA were 5.4 and $5.6 \%$, respectively.

\section{IgG Analysis}

Levels of IgG were determined by ELISA using bovine $\mathrm{IgG}$, bovine reference serum standards, and sheep anti-bovine IgG-horseradish peroxidase conjugate (all from Bethyl Laboratories, Montgomery, TX). Sheep anti-bovine $\mathrm{IgG}$ was preadsorbed on the surface of microtiter wells. Colostrum (diluted $1: 10^{6}$ ) and standard samples (diluted to $500 \mathrm{ng} / \mathrm{mL}$ ) were added in duplicate at $100 \mu \mathrm{L} /$ well and incubated at $25^{\circ} \mathrm{C}$ for $1 \mathrm{~h}$. After the plates were washed 4 times with dilution buffer, $100 \mu \mathrm{L}$ of anti-IgG detection antibody was added to each well and incubated at $25^{\circ} \mathrm{C}$ for $1 \mathrm{~h}$. After the plates were washed 4 times, $100 \mu \mathrm{L}$ of streptavidinhorseradish peroxidase was added to each well. Plates were incubated at $25^{\circ} \mathrm{C}$ for $30 \mathrm{~min}$, and then washed again 4 times, and a chromogenic substrate $-3,3^{\prime}, 5,5^{\prime}$ tetramethylbenzidine - was added to each well. After incubating plates in the dark at $25^{\circ} \mathrm{C}$ for $30 \mathrm{~min}, 100$ $\mu \mathrm{L}$ of dilute sulfuric acid was added to terminate the reaction. The respective plates were read in a model MR5000 microplate autoreader (Dynatech, Guernsey, $\mathrm{UK})$ at $450 \mathrm{~nm}$. The IgG levels were determined by comparison with the linear plot of the reference standards. The inter- and intraassay coefficients of variation of $\operatorname{IgG}$ were 3.3 and $3.2 \%$, respectively. 


\section{Fertility Features}

Cows were routinely checked by the local veterinarian between 5 and $12 \mathrm{~d}$ postpartum. Based on appearance of the uterine discharge, cows were classified as positive for endometritis or none. At the same time, cows were scored for BCS and checked for ketosis in urine samples (Ketostix, Bayer AG, Leverkusen, Germany). Cows were scored again for body condition at peak lactation; that is, 40 to 50 DIM. Cows positive for endometritis were treated with intrauterine antibiotics until discharge was resolved. Cows diagnosed with ketosis were drenched with propylene glycol (300 $\mathrm{mL} /$ cow per day). In severe cases, corticosteroids were administered simultaneously.

Multiparous and primiparous cows were inseminated upon standing heat after voluntary waiting periods of 60 and $80 \mathrm{~d}$, respectively. Cows that were not observed to be in heat after the voluntary waiting period were diagnosed by the local veterinarian for ovarian activity, and treated with prostaglandin or Ovsynch; they were then inseminated when they appeared to be in heat. Cows that returned in heat were inseminated again.

Pregnancy diagnoses were performed at $42 \mathrm{~d}$ postinsemination and again before drying off to confirm pregnancy. The examined fertility parameters were (1) interval from calving to pregnancy; (2) days from calving to first insemination (DI); and (3) conception rate on first insemination (i.e., the number of pregnant cows divided by the total number of first inseminations). Cows with a calving-to-pregnancy interval $>150$ $\mathrm{d}(13.5 \%)$ were excluded from the analysis.

\section{Statistical Analysis}

Data analysis was carried out with SAS procedures (SAS Institute, 2002). Variables not associated with reproduction were analyzed by the MIXED procedure. Continuous variables (monthly milk and ECM yields, protein and fat percentages, protein and fat yields, NEFA and IgG concentrations) were analyzed as repeated measurements. The effect of BCS at wk 1 of DP and the change in BCS between wk 1 postpartum and wk 1 of DP on milk and ECM yields in the subsequent lactation were analyzed as class variables. A season-ofcalving effect was initially tested for but was found insignificant and therefore excluded from the final model. Herd was a random effect where the fixed effects in the model were treatment (40-d or 60-d DP) and age (parity $=2$ or parity $>2$ ). The effects of herd $\times$ treatment, age $\times$ treatment, herd $\times$ age $\times$ treatment, and age $\times$ treatment $\times$ month of lactation (ML) were tested. The differences between the categories were tested using the PDIFF option (SAS Institute, 2002).
The final model used was as follows:

$$
\begin{gathered}
\mathrm{Y}_{h i j k l m}=\mu+\mathrm{F}_{h}+\mathrm{T}_{i}+\mathrm{L}_{j}+\mathrm{C}(\mathrm{F} \times \mathrm{T} \times \mathrm{L})_{h i j k} \\
+\mathrm{ML}_{h i j k l}+\left(\mathrm{ML}_{h i j k l} \times \mathrm{ML}_{h i j k l}\right)+\left(\mathrm{ML}_{h i j k l}\right. \\
\left.\times \mathrm{ML}_{h i j k l} \times \mathrm{ML}_{h i j k l}\right)+\mathrm{E}_{h i j k l m},
\end{gathered}
$$

where $\mathrm{Y}_{h i j k l m}$ is the dependent variable, $\mu$ is the overall mean, $\mathrm{F}_{h}$ is herd effect $h, \mathrm{~T}_{i}$ is treatment effect $i, \mathrm{~L}_{j}$ is parity $(j=2$ or $>2), \mathrm{C}(\mathrm{F} \times \mathrm{T} \times \mathrm{L})_{h i j k}$ is cow $k$ nested in herd, cow nested in treatment $i$, and cow nested in parity $j, \mathrm{ML}_{h i j k l}$ is month in milk, and $\mathrm{E}_{h i j k l m}$ is a random residual.

To explore the variability between herds, a similar model was run in which the 3 disease effects were examined as class variables: metritis $(0=$ negative or $1=$ positive $)$, ketosis $(0=$ negative or $1=$ positive $)$, and mastitis $(0=\mathrm{SCC}<250,000 \mathrm{cell} / \mathrm{mL}$ or $1=\mathrm{SCC}$ $\geq 250,000 \mathrm{cell} / \mathrm{mL}$ ). Udder health status after calving was categorized as follows: new, cure, and static infection incidence according to SCC difference between examined milk tests (i.e., last milk test before drying and the first milk test after calving). The interactions of each disease with farm and treatment were also tested. The distribution (\%) of noninfected and infected cows between categories and of each disease was tested by $\chi^{2}$ test in the FREQ procedure. In addition, udder health status after calving was analyzed. The analysis of fertility performance was carried out by PHREG, FREQ, and LOGISTIC procedures of SAS (SAS Institute, 2002).

Analysis of accumulated milk and ECM yields for 305 DIM following the experimental DP plus the yield of additional days of the previous lactation for the 40-d DP versus $60-d$ DP cows was carried out by using the same general model. The error term was cow nested within lactation by treatment and herd.

An additional analysis of accumulated milk and ECM yields for 2 consecutive lactations was carried out on cows that had the same actual dry days within the range for defining the DP experimental group (i.e., short or long DP). Herd was a random effect where the fixed effects in the model were treatment (40-d or $60-\mathrm{d}$ DP) and age (parity $=2$ or parity $>2$ ). The effects of herd $\times$ treatment and age $\times$ treatment were tested. The differences between the categories were tested using the PDIFF option (SAS Institute, 2002). The data were collected from the herds that were included in our research. The model used for this analysis was based on the mixed model as described above but without the repeated measures. Least squares means and adjusted SEM are presented in Tables 1 to $4 ; P<0.05$ was used for significance testing unless otherwise stated. 
Table 2. Average milk and ECM yields $(\mathrm{kg} / \mathrm{d})$ for $305 \mathrm{~d}$ from cows in 2 experimental dry period (DP) $\operatorname{groups}^{1}$

\begin{tabular}{|c|c|c|c|c|c|c|c|c|}
\hline Herd & \multicolumn{4}{|c|}{ Milk } & \multicolumn{4}{|c|}{ ECM } \\
\hline 1 & $37.64^{\mathrm{a}}$ & $39.04^{\mathrm{b}}$ & 0.53 & 0.05 & $37.10^{\mathrm{a}}$ & $38.12^{\mathrm{b}}$ & 0.47 & 0.05 \\
\hline 3 & 39.12 & 39.76 & 0.86 & 0.45 & 39.54 & 40.11 & 0.76 & 0.45 \\
\hline 4 & $43.71^{\mathrm{a}}$ & $45.37^{\mathrm{b}}$ & 0.55 & 0.05 & 44.77 & 45.60 & 0.49 & 0.08 \\
\hline 5 & 36.53 & 37.34 & 0.64 & 0.21 & 35.80 & 36.60 & 0.56 & 0.12 \\
\hline
\end{tabular}

$\overline{\mathrm{a}, \mathrm{b}}$ Means within the same row with different superscripts differ $(P \leq 0.05)$.

${ }^{1} 40-\mathrm{d}=$ short DP (40 d dry); 60-d = conventional DP (60 d dry).

\section{RESULTS}

\section{Days Dry and Milk and ECM Yields}

Actual number of days dry was similar to the planned DP $(42.1 \pm 0.4 \mathrm{~d}$ for the 40-d DP group and $61.3 \pm$ $0.28 \mathrm{~d}$ for the $60-\mathrm{d}$ DP group).

Average milk and ECM yields of all 60-d DP cows were higher than those of the 40-d DP cows $(P<0.05)$. However, large variability was observed among herds. The significantly higher milk yield of the 60-d DP group was observed on only 2 farms, and higher ECM yield was noted on only 1 farm $(P<0.05)$. The herd $\times$ treatment interaction was significant $(P<0.05)$, reflected in substantial differences in DP-duration effects between the herds (Table $2 ; P<0.05$ ).

In the primiparous cows, no significant differences in milk or ECM yield were observed between the 2 DP groups, except on 1 farm $(P>0.05$; Table 3$)$. In contrast, the multiparous cows subjected to a $60-\mathrm{d}$ DP had greater milk and ECM yields than the 40-d DP group in 3 out of 5 herds $(P<0.05)$. Analysis of the lactation curves showed that milk and ECM yields of primiparous cows after calving did not differ between the 2 groups for the whole lactation (Figure 1). However, milk and ECM yields of multiparous cows until 180 DIM were higher for the 60-d DP group compared with 40-d DP group $(P<0.05)$.

Cows allocated to the 40-d DP group had, on average, $19.5 \pm 0.3$ additional milking days in lactation before drying off compared with the 60-d DP cows. Adding the milk and ECM yields of the additional milking days from the previous lactation to the 305-d yield of the subsequent lactation showed that milk yield of all cows in the 40-d DP group was significantly higher than that of the $60-\mathrm{d}$ DP group $(13,000$ vs. $12,470 \mathrm{~kg}$, SEM = $171 ; P=0.001)$. The ECM yield was also significantly higher for the 40-d DP versus 60-d DP group (12,957 vs. $12,404 \mathrm{~kg}, \mathrm{SEM}=156 ; P=0.01)$. The significant difference in favor of the 40-d DP was similar in both primiparous and multiparous cows $(P<0.05)$.

\section{Milk and ECM Yields of 2 Consecutive Years}

To explore the residual, delayed effect of short or long DP, we analyzed the difference between the accumulated milk and ECM yields of 2 consecutive lactations (305 d each) following the experimental DP. As mentioned above, cows involved in this analysis had the same DP lengths for the 2 consecutive lactations. We observed no significant differences between the 2 groups for milk or ECM yields $(P>0.05$; Figure 2$)$, except for 1 herd that exhibited higher milk production by the $40-\mathrm{d}$ DP cows $(P<0.05)$.

\section{Milk Composition}

Overall, milk fat percentage did not differ between the $2 \mathrm{DP}$ groups $(P>0.05)$ and was not affected by

Table 3. Average 305-d milk yield for primiparous and multiparous cows in 2 experimental dry period (DP) groups ${ }^{1}$

\begin{tabular}{|c|c|c|c|c|c|c|c|c|}
\hline \multirow[b]{2}{*}{ Herd } & \multicolumn{4}{|c|}{ Primiparous cows } & \multicolumn{4}{|c|}{ Multiparous cows } \\
\hline & $40-\mathrm{d}$ & $60-d$ & SEM & $P<$ & $40-\mathrm{d}$ & $60-d$ & SEM & $P<$ \\
\hline 1 & 36.70 & 37.80 & 0.70 & 0.13 & $38.60^{\mathrm{a}}$ & $40.27^{\mathrm{b}}$ & 0.75 & 0.05 \\
\hline 2 & 36.17 & 35.80 & 1.74 & 0.80 & $37.42^{\mathrm{a}}$ & $40.74^{\mathrm{b}}$ & 1.5 & 0.05 \\
\hline 3 & 38.36 & 38.77 & 1.07 & 0.70 & 39.90 & 40.75 & 1.36 & 0.5 \\
\hline 4 & $42.26^{\mathrm{a}}$ & $44.83^{\mathrm{b}}$ & 0.74 & 0.05 & 45.15 & 45.90 & 0.83 & 0.36 \\
\hline 5 & 36.05 & 36.15 & 1.05 & 0.90 & $37.01^{\mathrm{a}}$ & $38.50^{\mathrm{b}}$ & 0.72 & 0.03 \\
\hline All cows & 37.90 & 38.67 & 0.50 & 0.13 & $39.60^{\mathrm{a}}$ & $41.20^{\mathrm{b}}$ & 0.50 & 0.05 \\
\hline
\end{tabular}

${ }^{\mathrm{a}, \mathrm{b}}$ Means within the same row with different superscripts differ $(P \leq 0.05)$.

${ }^{1} 40-\mathrm{d}=$ short DP (40 d dry); 60-d = conventional DP (60 d dry). 

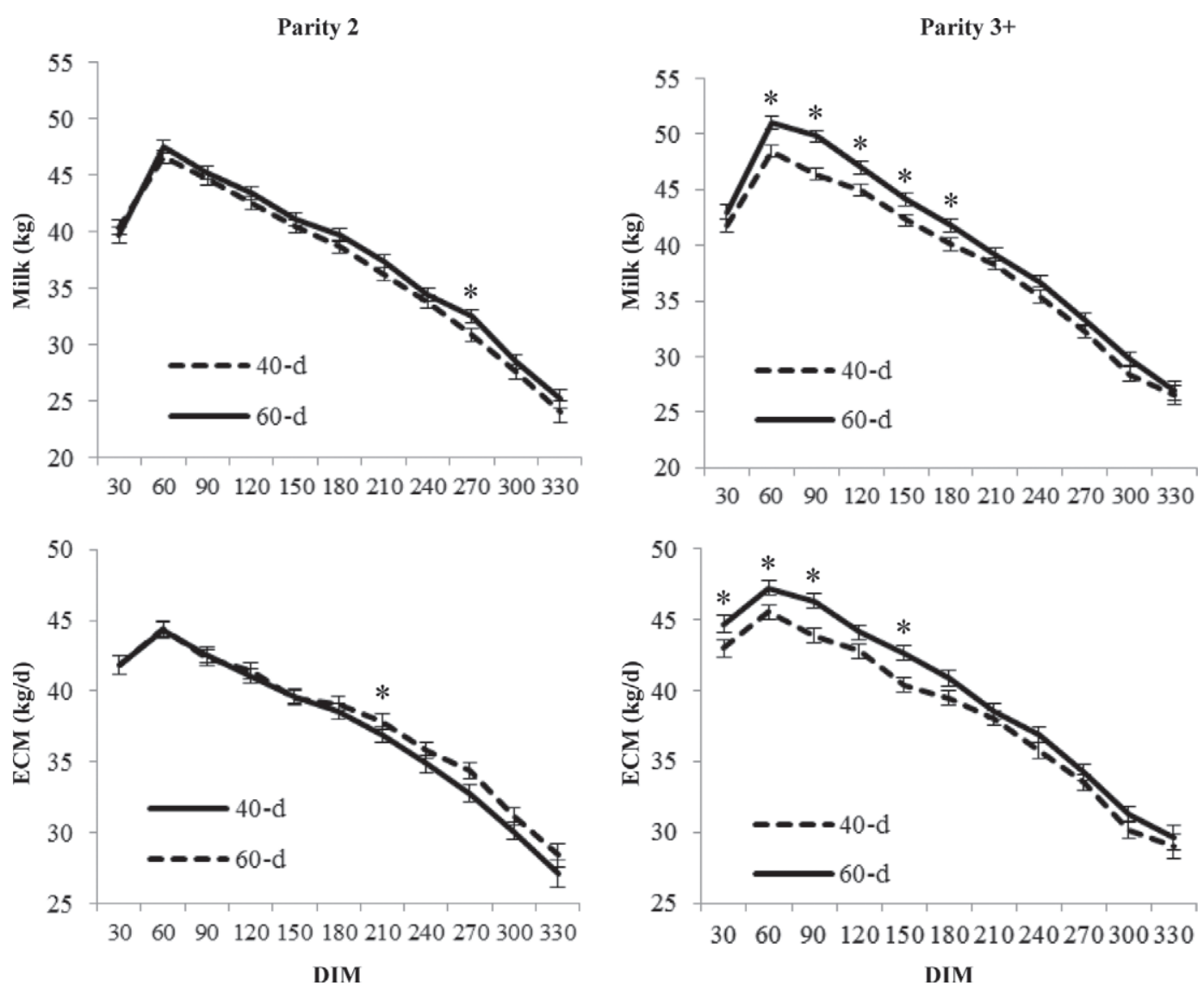

Figure 1. Daily milk and ECM yields of subsequent lactation of primiparous cows (parity 2) and multiparous cows (parity $3+$ ) after a short dry period $(40 \mathrm{~d})$ or a conventional dry period $(60 \mathrm{~d})$. Asterisk denotes significant difference $(P<0.05)$ between treatments. Data are presented as least squares means \pm SEM.

parity $(P>0.05)$. However, it should be noted that the milk fat percentage of the 60 -d DP group was significantly higher than that of the 40-d DP group during the first month of lactation (4.05 vs. 3.93, $P<0.05$; Figure 3A). The milk fat yield of 60 -d DP cows was higher $(P<0.05)$ than that of the 40-d DP cows for all cows in the model. Milk fat yield was also higher for the 60 -d DP cows between mo 2 and 6 of lactation $(P$ $<0.05$; Figure 3B).

Milk protein percentage was higher in 40-d DP cows than in 60 -d DP cows (3.19 vs. 3.16, SEM $=0.013 ; P=$ 0.02 ). In the primiparous cows, we found no significant difference between the 2 DP groups, but in the multiparous cows, the 40-d DP cows produced milk with a higher protein percentage than the $60-\mathrm{d}$ DP cows $(3.16$ vs. $3.11, \mathrm{SEM}=0.02 ; P=0.02)$. An analysis of the lactation curves indicated that the difference in milk protein percentage prevailed mainly between 30 and 150 DIM (Figure 3C). The average milk protein yield was higher for the 60-d DP cows than for the 40-d DP cows $(1.21$ vs. $1.19 \mathrm{~kg}, \mathrm{SEM}=0.009 ; P=0.01)$. This difference prevailed on 3 out of the 5 farms. The higher milk protein yield of 60-d DP cows was significant in mo 5 and 6 of lactation $(P<0.05)$ and tended to be higher until mo 9 of lactation $(P=0.07$; Figure 3D).

The milk fat-to-protein ratio was higher in the 60-d DP cows than in the 40-d DP cows for the first 5 mo of lactation $(P<0.05$; Figure 4$)$. The treatment $\times$ parity interaction was not significant $(P<0.05)$. However, the higher ratio during the first 5 mo of lactation derived from significant differences between the 2 experimental groups of the multiparous cows only $(P<0.05)$.

\section{BCS}

Body condition score measured 1 wk after drying off did not significantly differ between $40-\mathrm{d}$ and $60-\mathrm{d}$ DP cows $(3.32 \pm 0.05$ and $3.2 \pm 0.05$, respectively; $P>$ 0.05 ), but 1 wk after calving, their respective BCS were 3.15 and $3.05 \pm 0.03(P=0.01)$. The treatment $\times$ parity interaction at drying off and at calving was not significant $(P=0.99)$.

Cows of the 60-d DP group lost more BCS between 1 wk after calving and peak milk ( +6 to +7 wk) com- 
Two consecutive lactations
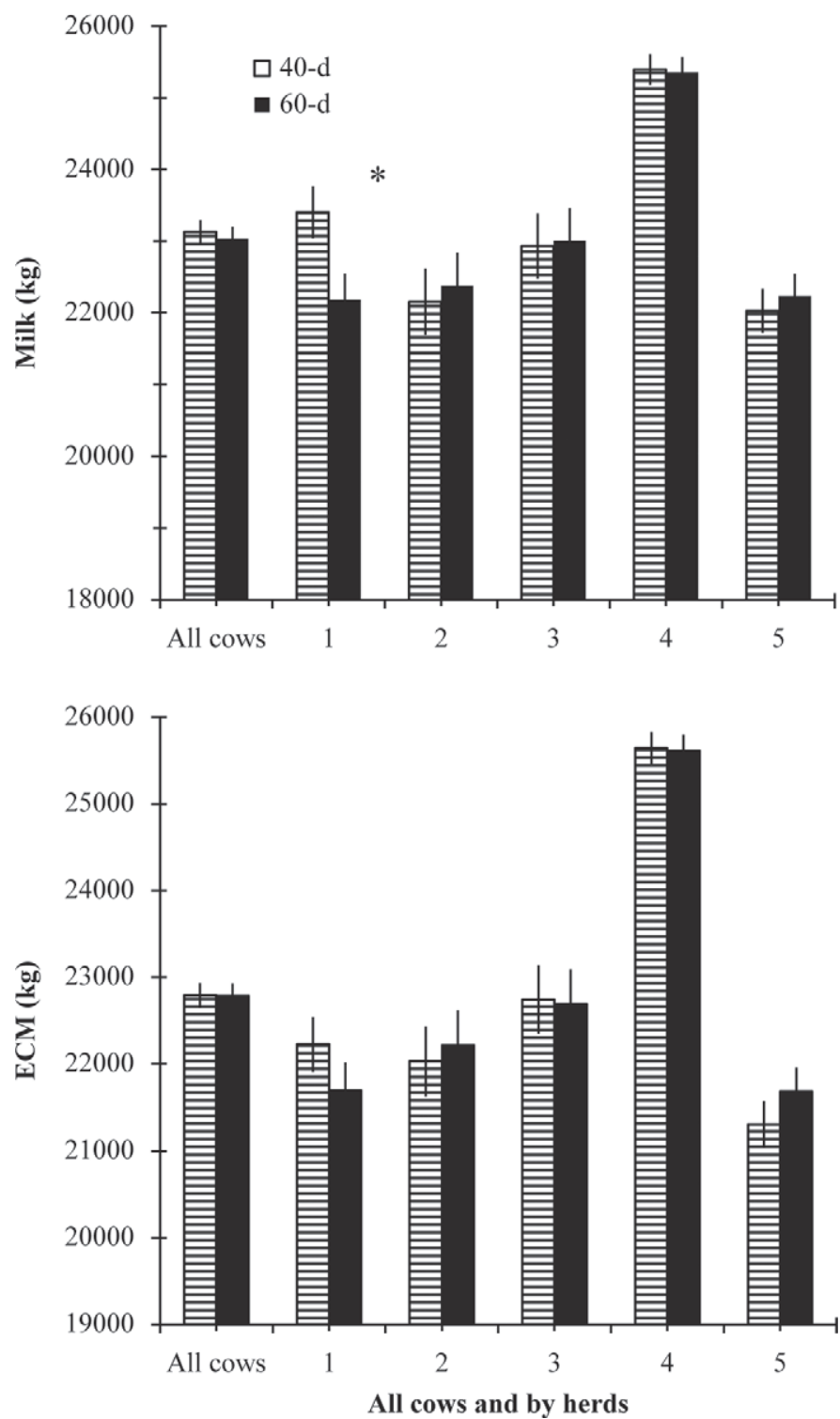

Figure 2. Accumulated milk and ECM yields of 2 subsequent 305$\mathrm{d}$ lactations of cows after either a short dry period (40-d) or a conventional dry period (60-d). Asterisk denotes significant difference $(P<$ 0.05 ) between treatments. Data are presented as least squares means \pm SEM.

pared with the $40-\mathrm{d}$ DP $(-0.37$ vs. $0.32, \mathrm{SEM}=0.007$; $P<0.0001)$. The treatment $\times$ parity interactions were not significant $(P=0.9)$, indicating that this difference was not affected by parity.

Milk and ECM yields of all cows assigned to the 40-d DP and 60-d DP groups that were classified as "fat" and "normal" in wk 1 of drying off did not differ $(P>0.05)$. The thin cows of both treatments produced higher milk and ECM yields in the subsequent lactation compared with the other 2 BCS categories $(P<0.05$; Figure 5$)$, but the thin cows from both treatments did not differ significantly $(P>0.05)$. The body condition status $\times$ treatment interaction was not statistically significant $(P>0.05)$.

The interaction of treatment $\times$ change in BCS between +1 wk and -1 -wk_DP was not significant $(P>$ 0.05). Within treatment, cows that lost BCS (i.e., -1 ) produced higher milk and ECM yields $(P<0.05)$ in the subsequent lactation than those that gained BCS $(P<$ 0.05 ; Figure $6 \mathrm{~A}$ and $6 \mathrm{~B}$, respectively). The cows that did not change their BCS during the DP were intermediate between the 2 categories or similar to those that lost BCS. Between treatments, 60-d DP cows whose $\mathrm{BCS}$ did not change and cows that gained BCS during the DP produced higher milk and ECM yields than 40-d DP cows from the same categories.

\section{IgG Antibodies in Colostrum}

The concentrations of IgG in colostrum were examined in a subset of cows within 2 herds (26 cows in each DP group in one herd and 45 cows in each DP group in the second herd). The IgG concentrations of 40-d DP cows were similar to those of the 60 -d DP cows $(4,815$ vs. $4,891 \mathrm{mg} / \mathrm{dL}, \mathrm{SEM}=425$, respectively; $P=0.86$ ).

\section{Metabolic Status}

NEFA in the Blood. Prepartum serum content of NEFA was not significantly different between the $60-\mathrm{d}$ DP and 40-d DP groups 1 wk before expected calving $(565$ and $710 \mu \mathrm{Eq} / \mathrm{L}$, respectively, $\mathrm{SEM}=140 ; P>$ $0.05)$. The effect of parity was not significant $(P>$ 0.05). At 1 wk after calving, the 60-d DP cows had higher serum NEFA concentrations than the 40-d DP cows $(1,068$ vs. $747 \mu \mathrm{Eq} / \mathrm{L}, \mathrm{SEM}=174 ; P<0.05)$. This result was due to the higher NEFA concentrations in multiparous cows of the 60-d DP versus 40-d DP group $(1,211$ vs. $762 \mu \mathrm{Eq} / \mathrm{L}, \mathrm{SEM}=185 ; P=0.02)$. From $14 \mathrm{~d}$ postcalving on, we observed no significant difference between the 2 groups $(P>0.05)$. The magnitude of the difference between NEFA concentrations 1 wk before expected calving and 1 wk after calving was significantly higher in 60-d DP cows compared with 40-d DP cows $(P<0.05)$ and diminished later in lactation. However, the magnitude of the difference was numerically greater in 60-d DP cows until $42 \mathrm{~d}$ after calving, although not significant due to large variation between cows.

Metabolic Diseases and Mastitis. We observed some variability in 305-d milk and ECM yields between herds in response to DP length. To explore whether disease might explain this variability, milk and ECM yields were examined in each DP category within ev- 

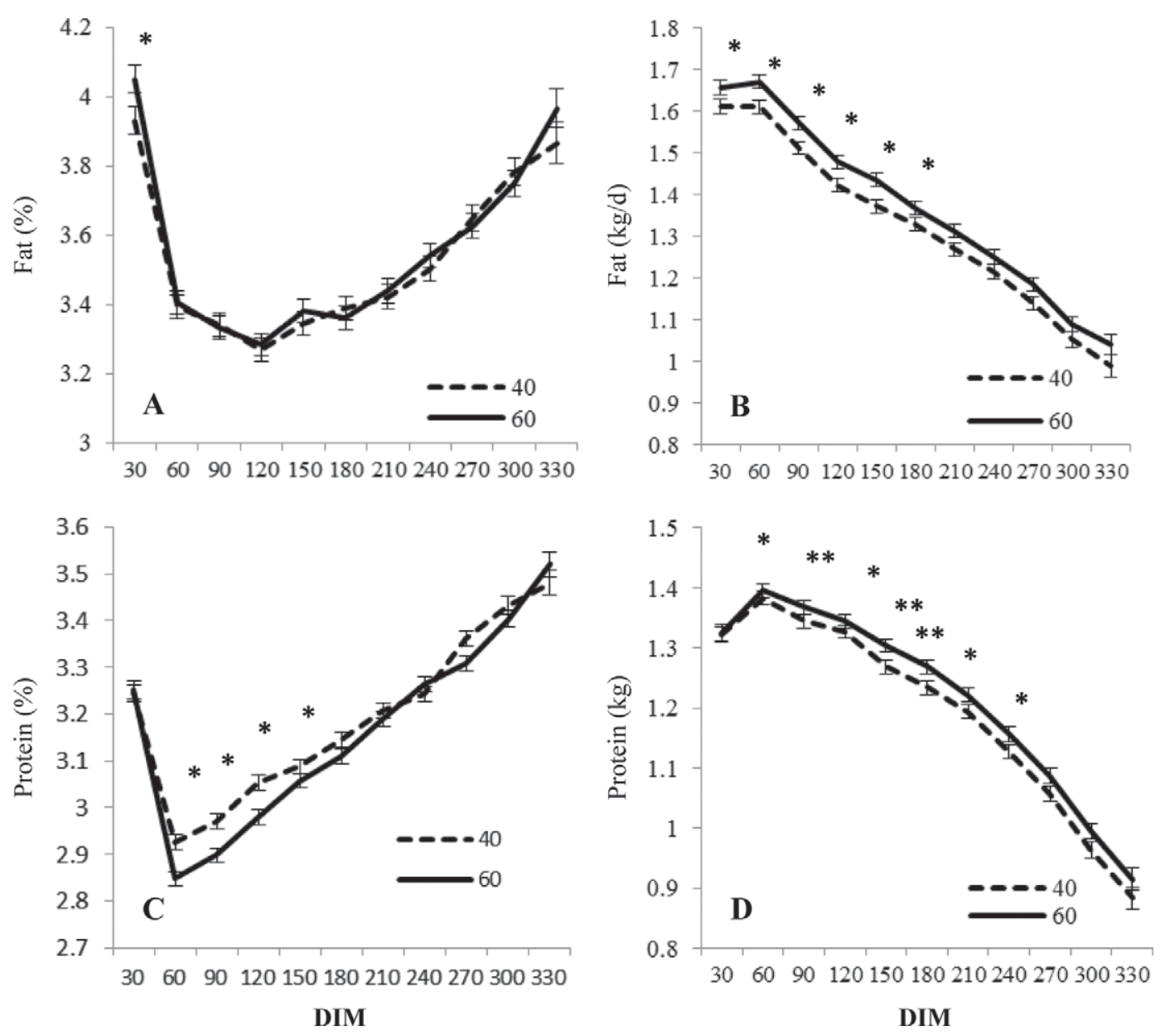

Figure 3. Fat content $(\%, \mathrm{~A})$, daily fat yield $(\mathrm{kg}, \mathrm{B})$, protein content $(\%, \mathrm{C})$, and daily protein yield $(\mathrm{kg}, \mathrm{D})$ in subsequent lactations of cows after either a short dry period $(40 \mathrm{~d})$ or a conventional dry period $(60 \mathrm{~d})$. ${ }^{*}$, **Significant differences between treatments at $P<0.05$ and $P<$ 0.01 , respectively. Data are presented as least squares means \pm SEM.

ery disease. The differences in milk yields (Table 4) between the categories of metritis and ketosis were not significant in any of the herds, whereas with mastitis, we detected a significant difference between categories all but one herd. The distribution of affected cows compared with nonaffected cows did not present any particular trend between herds in which milk yield of 60-d DP cows was significantly higher than that of 40-d DP cows, or between herds with similar milk yields for the 2 experimental DP lengths (Table 5). The distribution of udder health categories after calving (new, cure, and static infection incidence) did not differ between 40-d DP and 60-d DP groups within each farm. Furthermore, the appearance of new infection incidences was not associated with milk production (Table 6).

\section{Fertility}

Days to First Insemination. Cows of the 60-d DP group had longer DI compared with the 40-d DP group (71.3 vs. $77.4, \mathrm{SEM}=1.75 ; P=0.02)$. Parity $\times$ treatment interaction was not significant $(P=$ $0.5)$. Primiparous and multiparous cows in the 60-d DP group tended to have longer DI compared with their 40-d DP counterparts (69.7 vs. $74.5 \pm 2.7, P=0.07$; 65.1 vs. $68 \pm 2.04, P=0.10$, respectively). The proportion of cows in the 60-d DP group with more than 90 DI was $30.5 \%$ compared with $27 \%$ of cows in the $40-\mathrm{d}$ DP group $(P<0.05)$.

Days to Pregnancy. The 40-d DP group showed 10 fewer days to pregnancy than the 60-d DP group (116 vs. $126, \mathrm{SEM}=2.73 ; P=0.0002)$. The parity $\times$ treatment interaction tended to be significant $(P=$ 0.10). Primiparous cows in the 40-d DP group had 15 fewer open days than those in the longer DP group (112 vs. $127, \mathrm{SEM}=4.16 ; P<0.001)$. Multiparous cows presented a similar pattern but the difference was smaller (119 vs. $125, \mathrm{SEM}=3.25 ; P<0.05)$.

Conception Rate from First Insemination. The conception rate for all cows from first insemination was 


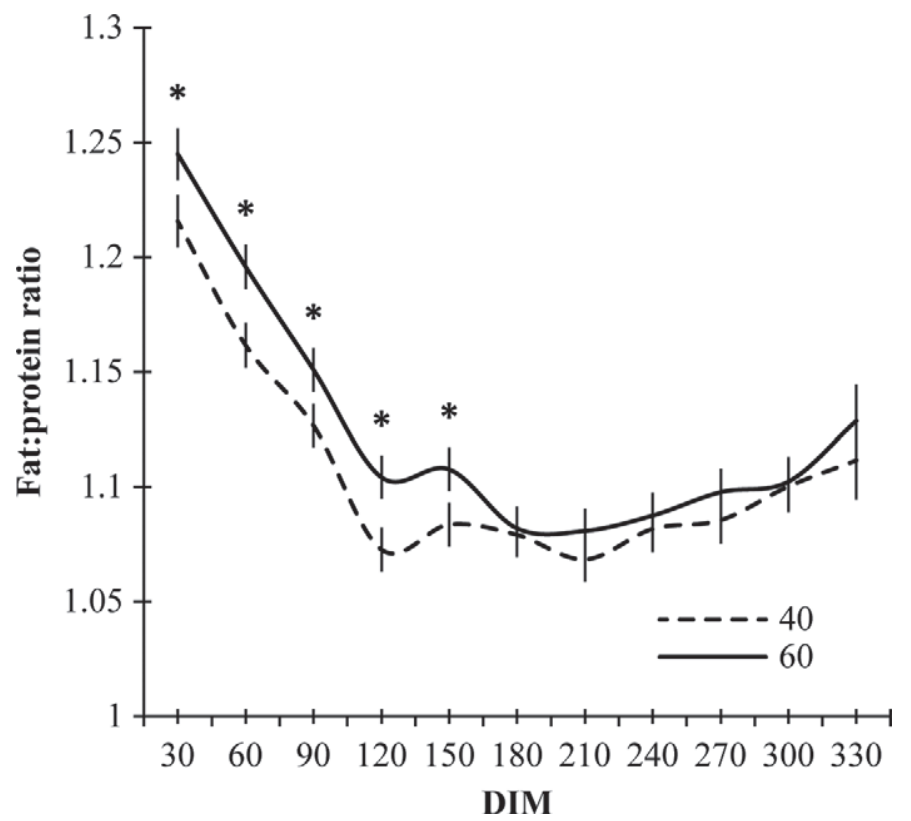

Figure 4. Fat:protein ratio of daily milk and ECM yields in subsequent lactation of primiparous cows (parity 2) and multiparous cows (parity $3+$ ) after either a short dry period $(40 \mathrm{~d})$ or a conventional dry period $(60 \mathrm{~d})$. Asterisk denotes significant difference $(P<0.05)$ between treatments. Data are presented as least squares means \pm SEM.

similar for both DP groups as reflected by LOGISTIC and $\mathrm{Q}^{2}$ procedures. Among the primiparous cows subjected to 40-d DP, $34 \%$ were pregnant within $150 \mathrm{~d}$ compared with $26 \%$ in the 60 -d DP group $(P<0.05)$. However, multiparous cows of the 2 group did not differ significantly. A smaller percentage of primiparous cows in the 40-d DP group were not pregnant after 150 DIM compared with that of the 60 -d DP cows (11 vs. $16 \%$, respectively; $P<0.05$ ). Similar but nonsignificant results between the 40-d and 60-d DP groups were found in multiparous cows (12.3 vs. $14 \% ; P>0.1)$.

\section{DISCUSSION}

In the last few decades, the optimality of the traditional DP length has been debated. Several studies examining shorter DP, some even less than $30 \mathrm{~d}$, have produced variable results. Other studies have shown that a 40-d DP can lead to decreased milk yield in the subsequent lactation due to insufficient time for mammary cell turnover (Capuco et al., 2003; Annen et al., 2007). In brief, the effect of a short DP is not well defined.

In the current study, we found that shortening the DP to $40 \mathrm{~d}$ decreased $305-\mathrm{d}$ milk yield by only $3 \%$ and ECM yield by $2.4 \%$ compared with a $60-\mathrm{d}$ DP. These findings were valid when data were calculated irrespective of parity, and were found to be in accordance
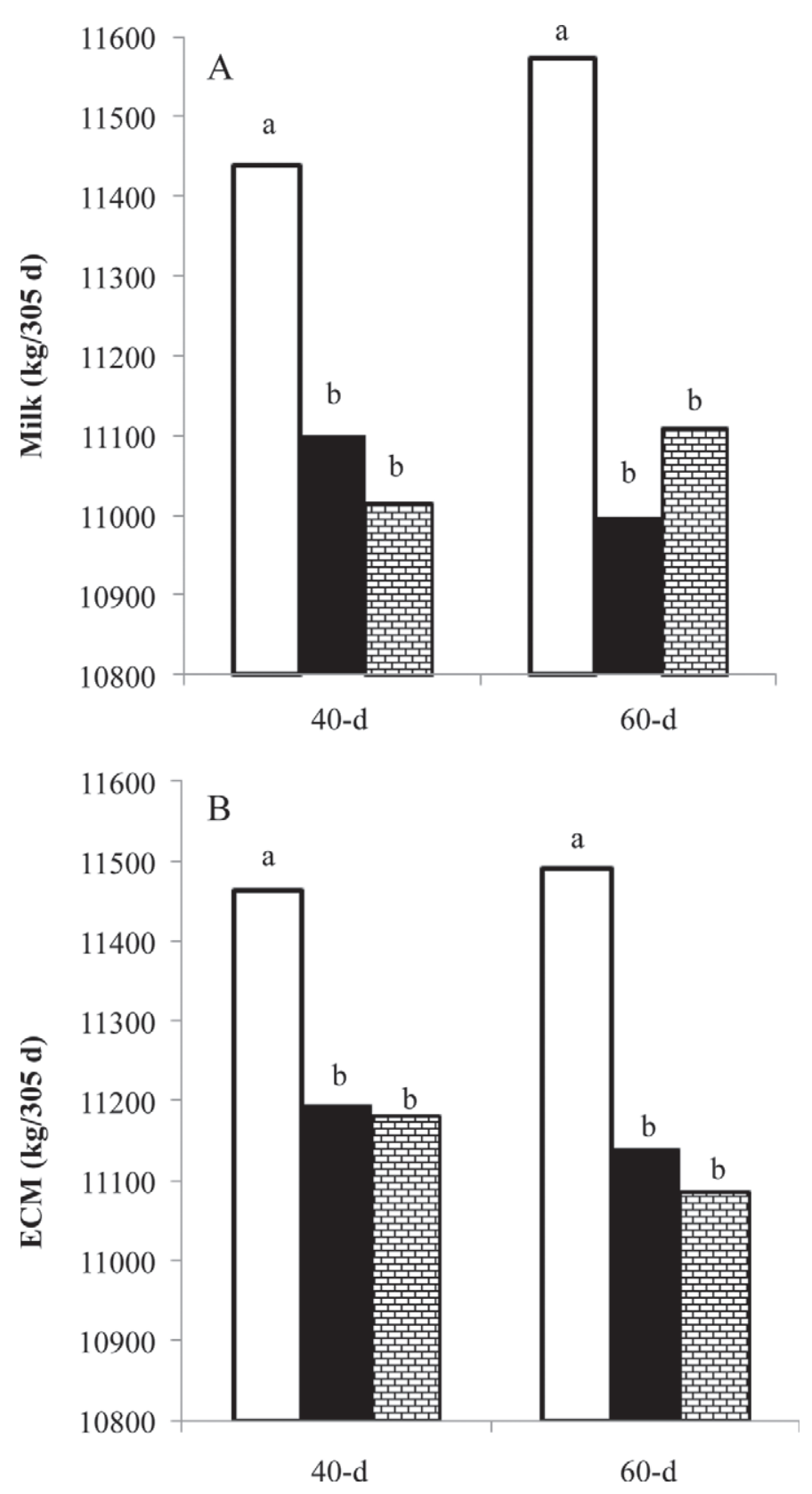

Figure 5. Milk (A) and ECM (B) yields (kg) of subsequent lactation $(305 \mathrm{~d})$ of cows categorized according to their BCS in the first week of drying off (-1-wk_DP): "fat" = BCS $>3.25$ (hatched bar); "normal" $=2.75<$ BCS $\leq 3.25$ (solid bar); "thin" = BCS $\leq 2.75$ (open bar). Milk and ECM yields were not statistically different between treatments, $P>0.05(\mathrm{SE}=140)$. Letters within treatments represent significant difference $(P<0.05)$ between categories.

with other studies (Rémond et al., 1997; Pezeshki et al., 2007; Watters et al., 2008). Other studies testing DP lengths of less than $40 \mathrm{~d}$ have reported greater milk losses of 12.8, 10.7, and 9.2\%, respectively (Sørensen and Enevoldsen, 1991; Rastani et al., 2005; BernierDodier et al., 2011) or no difference in the subsequent 

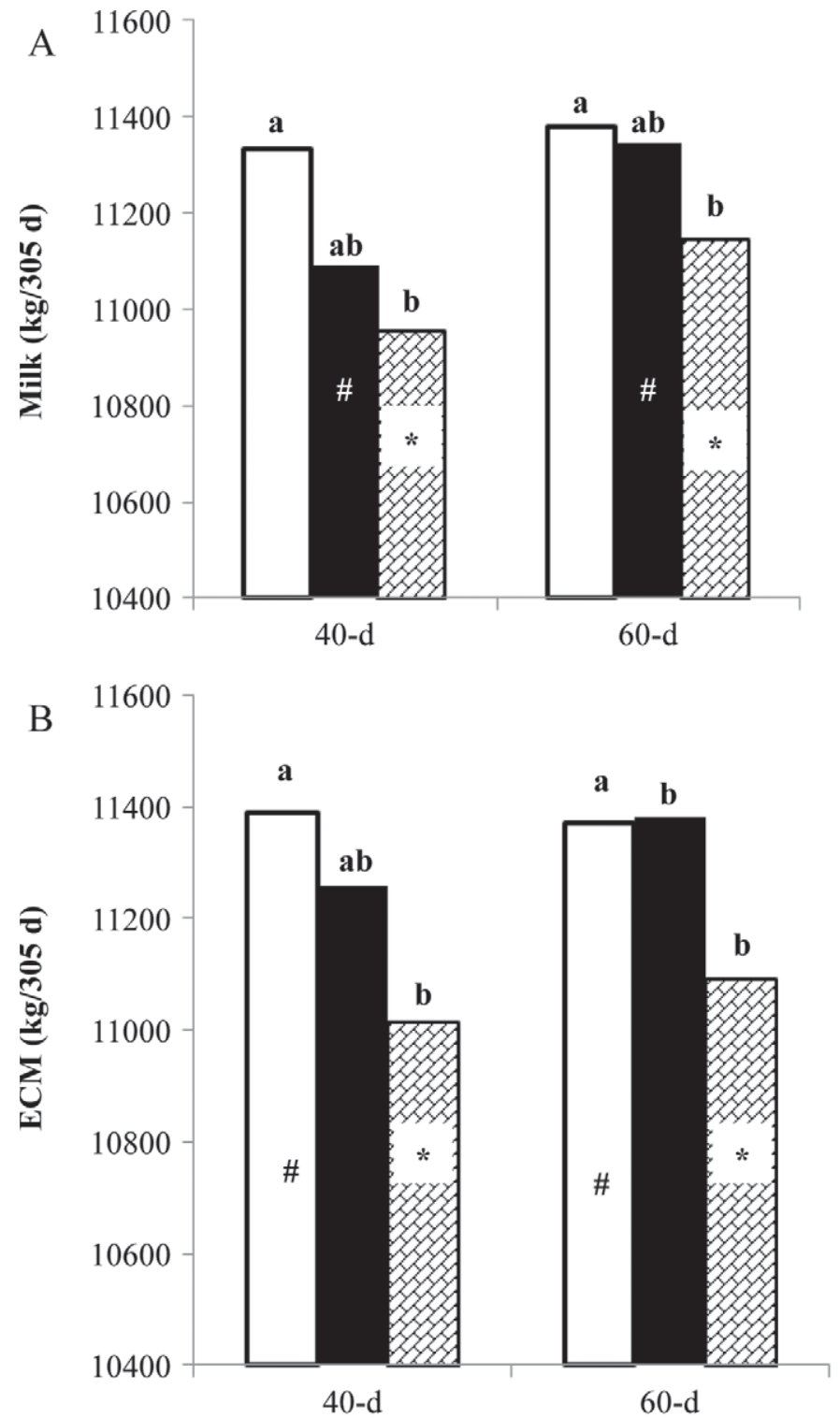

Change of BCS between +1 -wk and -1-wk_DP

Figure 6. Milk (A) and ECM (B) yields $(\mathrm{kg})$ of the subsequent lactation $(305 \mathrm{~d})$ of cows whose BCS changed between the first week $(+1$-wk) after calving and the first week of the drying-off period $(-1-$ wk_DP): cows that gained BCS (hatched bar), cows with unchanged BCS (solid bar), and cows that lost BCS (open bar). Letters (a, b) represent significant difference $(P>0.05)$ between categories within treatments; symbols $(*, \#)$ represent significant difference $(P<0.05)$ between same categories between treatments.

lactation between short (30 d) and long (60 d) DP (Gulay et al., 2003; Jolicoeur et al., 2009; Klusmeyer et al., 2009).

Although the cumulative data in the current study showed a significant difference between the 40-d and $60-d$ DP, the variability between herds was substantial; in 3 herds we observed no significant difference in milk or ECM yields between the 2 groups. High variability between herds has also been reported by others (Grummer and Rastani, 2004; Santschi et al., 2011a). The variability between herds in the current study probably resulted from management differences, such as barn construction, grouping of the dry cows (i.e., density), or local microclimate.

In contrast to other studies (Pezeshki et al., 2007; Watters et al., 2008; Bernier-Dodier et al., 2011; Santschi et al., 2011a; Collier et al., 2012), the parity effect in the current study was significant. The primiparous cows of the 40-d and 60-d DP groups produced similar milk and ECM yields in the subsequent lactation. In contrast, the 60-d DP multiparous cows produced significantly greater milk and ECM yields than the 40-d DP multiparous cows. Analyzing the lactation curves showed that milk and ECM yields of $60-\mathrm{d}$ DP multiparous cows are significantly higher until $180 \mathrm{~d}$ of lactation. This difference between the 2 treatments declined with advancing lactation and became insignificant, as reported by others (Klusmeyer et al., 2009; Bernier-Dodier et al., 2011). Nonetheless, this change in pattern did not affect the overall effect of DP length on milk and ECM production. However, the variability between herds should be considered; in 2 out of 5 farms in the current study, DP length had no significant effect on the multiparous cows. Such variations might be associated with cow density, feeding management, and cooling strategy during the DP under conditions of heat stress (Adin et al., 2009). Three out of 5 farms had comparable hot and humid summer climates, the fourth was characterized by moderate weather, and the fifth by hot and dry weather. However, despite the climate differences between the farms, overall management was similar: the same barns, similar rations, similar cooling routines, similar feeding strategy (i.e., TMR), similar dry treatment, and the same veterinarian routine (same company), among other factors. The extent of the between-herd variability in milk and ECM yields might also be explained by differences in 3 common major diseases - metritis, ketosis, and mastitis (as defined by SCC threshold). The risk of subclinical hypocalcemia, which is correlated with reproductive outcomes and other health disorders, is unlikely in all herds in Israel and in particular in the 5 herds that were involved in the current study due to rarity of clinical cases observed in cows from both groups. Prophylaxis through feeding of low-calcium diets throughout the dry period, as practiced on all Israeli farms, seems effective and hardly evidence for postpartum subclinical hypocalcemia. Nevertheless, the results of this analysis could not pinpoint any clear effect of those diseases on the differences between the 40-d and 60-d DP cows. The risk of new infections during DP or immediately after calving might also explain the between-herd variation 
Table 4. Average 305-d milk yield for nonaffected cows (0) or cows affected (1) by metritis or mastitis in 2 experimental dry period (DP) groups ${ }^{1}$

\begin{tabular}{|c|c|c|c|c|c|c|c|c|}
\hline $\begin{array}{l}\text { Category } \\
\text { and herd }\end{array}$ & \multicolumn{4}{|c|}{$40-d$} & \multicolumn{4}{|c|}{$60-d$} \\
\hline 2 & 36.62 & 35.34 & 2.48 & 0.60 & 36.08 & 39.13 & 2.07 & 0.14 \\
\hline 3 & 38.41 & 39.76 & 1.32 & 0.30 & 40.65 & 39.70 & 1.17 & 0.48 \\
\hline 4 & 41.39 & 43.71 & 0.99 & 0.07 & 44.08 & 45.60 & 1.28 & 0.24 \\
\hline \multicolumn{9}{|l|}{ Mastitis $^{2}$} \\
\hline 1 & $37.75^{\mathrm{b}}$ & $36.20^{\mathrm{a}}$ & 0.60 & 0.02 & $40.70^{\mathrm{b}}$ & $39.31^{\mathrm{a}}$ & 0.6 & 0.001 \\
\hline 2 & $37.91^{\mathrm{b}}$ & $34.04^{\mathrm{a}}$ & 1.01 & 0.02 & $38.42^{\mathrm{b}}$ & $36.79^{\mathrm{a}}$ & 0.98 & 0.001 \\
\hline 3 & 39.89 & 38.28 & 0.99 & 0.1 & 40.68 & 39.65 & 1 & 0.3 \\
\hline 4 & $44.07^{\mathrm{b}}$ & $40.48^{\mathrm{a}}$ & 0.6 & 0.001 & $46.40^{\mathrm{b}}$ & $43.26^{\mathrm{a}}$ & 0.72 & 0.001 \\
\hline 5 & $36.65^{\mathrm{b}}$ & 33.88 & 1.09 & 0.01 & $38.18^{\mathrm{b}}$ & $35.55^{\mathrm{a}}$ & 1.34 & 0.001 \\
\hline All cows & $39.26^{\mathrm{b}}$ & $36.58^{\mathrm{a}}$ & 0.4 & 0.001 & $39.74^{\mathrm{b}}$ & $39.65^{\mathrm{a}}$ & 0.30 & 0.05 \\
\hline
\end{tabular}

${ }^{\mathrm{a}, \mathrm{b}}$ Means within the same row with different superscripts differ $(P \leq 0.05)$.

${ }^{1} 40-\mathrm{d}=$ short DP (40 d dry); 60-d = conventional DP (60 d dry).

${ }^{2} 0=\mathrm{SCC}<250,000 \mathrm{cell} / \mathrm{mL} ; 1=\mathrm{SCC} \geq 250,000 \mathrm{cell} / \mathrm{mL}$.

in the current trial. This study indicates, however, that new infections after calving are unlikely to account for the between-herd variation in response to DP length.

Addition of milk and ECM produced during approximately 20 milking days of the previous lactation to the milk and ECM of the subsequent lactation of 40-d DP cows diminished the aforementioned milk yield differences between the 2 DP lengths, and brought the 40-d DP group to significantly higher production $(\sim 750$ $\mathrm{kg}$ ) than that reported by Santschi et al. (2011a; $\sim 530$ $\mathrm{kg}$ ). Accumulated milk and ECM yields of 40-d and 60-d DP cows in the current study during 2 consecutive lactations revealed no differences for either parity, although Kuhn et al. (2006) suggested that the production-maximizing length of the DP depends on parity.

In agreement with some previous studies (Lotan and Adler, 1976; Watters et al., 2008), but not with
Sørensen and Enevoldsen (1991), milk fat percentage was not affected by DP length. Nevertheless, milk fat percentage during the first $30 \mathrm{~d}$ of the subsequent lactation in multiparous cows in the 60-d DP group was significantly higher than that of multiparous cows in the 40-d DP group, paralleling the higher NEFA concentrations 1 wk after calving (1,111 vs. 755 , SEM = 110; $P<0.05)$. However, NEFA concentrations beyond $7 \mathrm{~d}$ postcalving were not significantly different between the 2 DP durations. Our results are partly in agreement with others (Rastani et al., 2005; Klusmeyer et al., 2009) who reported higher NEFA concentrations in cows subjected to a 56-d DP compared with a $28-\mathrm{d}$ DP for 2 wk after calving. The similarity between NEFA concentrations $1 \mathrm{wk}$ postpartum in the $2 \mathrm{DP}$ groups in the current study suggests that all cows were able to consume sufficient DM without mobilizing extensive

Table 5. Distribution (\%) of nonaffected cows (0) and affected cows (1) among categories of metritis, ketosis, and mastitis in 2 experimental dry period (DP) groups ${ }^{1}$

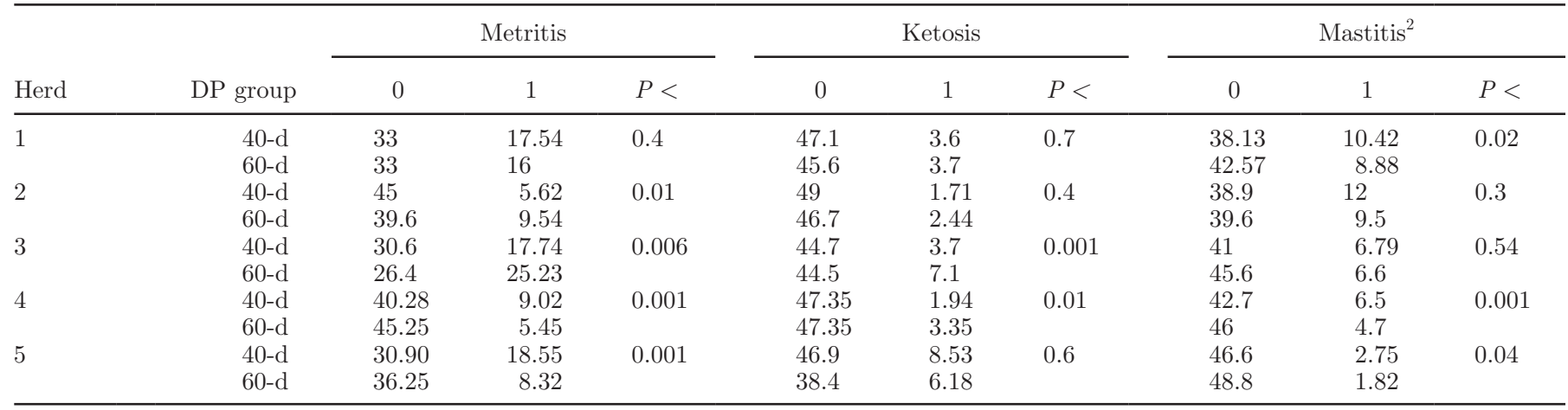

${ }^{1} 40$-d = short DP (40 d dry); 60-d = conventional DP (60 d dry).

${ }^{2} 0=\mathrm{SCC}<250,000 \mathrm{cell} / \mathrm{mL} ; 1=\mathrm{SCC} \geq 250,000 \mathrm{cell} / \mathrm{mL}$. 
Table 6. Distribution (\%) of cows with new, cure and static udder infection incidence in 2 experimental dry period (DP) groups ${ }^{1}$

\begin{tabular}{|c|c|c|c|c|c|c|c|}
\hline \multirow[b]{2}{*}{ Herd } & \multicolumn{2}{|c|}{ Cure $^{2}$} & \multicolumn{2}{|c|}{ New infection ${ }^{3}$} & \multicolumn{2}{|c|}{ Static $^{4}$} & \multirow[b]{2}{*}{$P<$} \\
\hline & $40-\mathrm{d}$ & $60-\mathrm{d}$ & $40-\mathrm{d}$ & $60-\mathrm{d}$ & $40-\mathrm{d}$ & $60-\mathrm{d}$ & \\
\hline 1 & 8.70 & 9.64 & 17.39 & 21.69 & 73.91 & 68.67 & 0.76 \\
\hline 2 & 4.35 & 5.26 & 21.74 & 31.58 & 73.91 & 63.16 & 0.75 \\
\hline 3 & 6.67 & 9.38 & 13.33 & 12.50 & 80.00 & 78.13 & 0.92 \\
\hline 4 & 8.24 & 6.98 & 10.59 & 9.30 & 81.18 & 83.72 & 0.90 \\
\hline 5 & 11.54 & 6.00 & 7.69 & 3.45 & 80.77 & 90.55 & 0.12 \\
\hline
\end{tabular}

fat reserves for milk production (Watters et al., 2008; Bernier-Dodier et al., 2011). However, this does not agree with the higher milk fat-to-protein ratio at the onset of lactation and later (until mo 5 of lactation) for 60-d DP multiparous cows, which coincided with higher milk and ECM production throughout the first 180 DIM and might indicate higher body-fat mobilization during this time (Heuer et al., 1999, 2000). Thus, it appears that 60-d DP multiparous cows have a more pronounced postpartum negative energy balance compared with 40-d DP cows. The higher milk fat yield noted in the current study in the 60-d DP multiparous cows is in agreement with Sørensen and Enevoldsen (1991) but not with others (Annen et al., 2004; Rastani et al., 2005; Pezeshki et al., 2007).

A higher protein percentage was found in the milk of multiparous cows of the 40-d DP group, in agreement with others (Annen et al., 2004; Rastani et al., 2005) but not with Sørensen and Enevoldsen (1991) or Gulay et al. (2003). However, the higher protein yield of the 60-d DP multiparous cows was similar to that reported by others (Sørensen and Enevoldsen, 1991; Annen et al., 2004). Thus, based on previous studies and the current findings, shortening the DP seems to decrease protein yield.

The higher BCS after calving of cows in the 40-d DP group was also found at peak lactation, a result that coincides with other reports (Gulay et al., 2003; Pezeshki et al., 2007; Velasco et al., 2008). The treatment $\times$ parity interaction at drying off and at calving was not significant $(P=0.99)$. In addition, the improved BCS after calving of 40-d DP cows that were fed only 1 ration during the $\mathrm{DP}$ suggests better adaptation to DP and also that the additional days of milking, at the end of the previous lactation, did not affect body-fat reserves. The latter was also suggested by Santschi et al. (2011a), who found that postcalving BCS is not affected by DP length.
The decrease in BCS as lactation progressed in both groups - but to a greater extent in the 60-d DP groupwas similar to that found by Watters et al. (2008). The thin cows (BCS $\leq 2.75)$ at the onset of the DP in both groups produced more milk in the subsequent lactation than normal $(2.75<\mathrm{BCS} \leq 3.25)$ and fat $(\mathrm{BCS}>3.25)$ cows. Other parameters, such as fertility and health issues, should be carefully monitored. The definition of "thin" should also be used with caution, because in commercial herds, there are high-producing cows with BCS lower than the above threshold, and those cows were excluded from our study. Obviously, we expect cows to maintain or gain fat reserves slightly during the DP, in preparation for higher milk production in the subsequent lactation. But gain of more than half a unit is mostly not beneficial. Therefore, the fact that cows in the current study gained BCS units during the DP produced less milk than those that lost BCS units was not surprising.

Colostrum quality was measured by IgG concentration, and no differences were observed between the 2 DP groups. Similar results were published by others (Annen et al., 2004; Rastani et al., 2005), even when DP was reduced to fewer days dry than our 40-d DP (30 and $28 \mathrm{~d}$, respectively). Omitting the DP completely may reduce the $\operatorname{IgG}$ concentration in the colostrum due to a dilution effect caused by higher milk production immediately after calving (Rastani et al., 2005). However, no evidence exists of a negative effect when reducing the DP to no less than 4 wk. Thus, a short DP does not negatively affect the $\operatorname{IgG}$ concentrations.

Shortening the DP improved reproductive efficiency. Days to pregnancy for all parities, were significantly decreased in 40-d DP cows, and more so in the primiparous cows ( $15 \mathrm{~d}$ less vs. $6 \mathrm{~d}$ less for multiparous cows). This result is in contrast to Watters et al. (2009), who showed only a tendency toward fewer days to pregnancy and only for multiparous cows, and to Lotan and Adler 
(1976), who reported similar days to pregnancy with $30-\mathrm{d}$ and $60-\mathrm{d}$ DP. Days to first insemination were decreased in 40-d DP cows (by approximately $6.5 \mathrm{~d}$ ) with a more pronounced difference in primiparous cows, which is in agreement with others (Gümen et al., 2005; Watters et al., 2009). The first-service conception rate was higher for primiparous 40-d compared with 60-d DP cows, in contrast to previous findings (Pezeshki et al., 2007; Watters et al., 2009) and similar in multiparous cows of both DP groups, in agreement with Watters et al. (2009). Time to first postpartum ovulation is associated with conception rates and interval from calving to conception, and to the general reproductive performance of dairy cows (Stevenson et al., 1983; Staples et al., 1990; Darwash et al., 1997). Although days to first postpartum ovulation was not measured in this study, it might be hypothesized that this was the reason for the better reproductive performance of cows in the 40-d (vs. 60-d) DP group, primiparous cows in particular.

Collectively, it seems that shortening the DP from 60 to $40 \mathrm{~d}$ does not have any deleterious effect on milk production through 2 consecutive lactations, suggesting a long-run effect. The BCS after calving was higher in 40-d DP cows. Moreover, a short DP was associated with reduced loss of BCS units between 1 wk after calving and peak milk ( +6 to +7 wk) and decreased serum NEFA concentrations 1 wk after calving. In light of these findings, it seems that a short DP induced positive energy status after calving, associated with improved reproductive parameters.

\section{CONCLUSIONS}

Milk and ECM yields did not differ in primiparous cows between the 2 experimental groups, but were higher in multiparous cows in the 60-d compared with the 40-d group. However, variability between herds was substantial and cannot be ignored. Adding milk and ECM yields from $\sim 20 \mathrm{~d}$ of the previous lactation to yields of the subsequent lactation revealed that milk yields of all cows in the 40-d DP group were significantly higher than those of the 60-d DP cows. Moreover, shortening the DP between 2 adjacent lactations did not reduce the accumulated milk and ECM yields in the long run, suggesting that a short DP $(\sim 40 \mathrm{~d})$ can be applied as a routine management tool for all parities. The observed improvements in reproduction and energy balance, as reflected by lower NEFA concentrations after calving and fat-to-protein ratio in the milk, support this suggestion. Shortening the DP did not negatively affect colostrum quality, as determined by IgG concentration. The reproductive performance of cows assigned to the 40-d DP group was improved, as reflected by fewer days to first insemination, a lower proportion of cows with $>90 \mathrm{~d}$ to first insemination, fewer days to pregnancy (more pronounced in primiparous cows), more primiparous cows pregnant from first insemination, and fewer primiparous cows not pregnant after 150 DIM. In regions such as Israel, Spain, and Florida, milk production during the hot season decreases because of environmental conditions. Concurrently, milk consumption is highest in this season relative to the rest of the year. This gap between production and consumption leads dairy plants to raise prices for milk and its components. Shortening the DP during this season might provide an appropriate solution for dairy managers, with none of the aforementioned harmful effects if the net income from milk compensates for possible lower production.

\section{ACKNOWLEDGMENTS}

The authors thank all of the farmers who were involved in this research. Without their long-term cooperation, it would never have been completed. The authors also thank Uzi Moallem (Institute of Animal Science, Volcani Center, Bet-Dagan, Israel) and Jacob Brenner (Prevention of Ruminant Neonatal Disease Unit, Kimron Veterinary Institute, Bet-Dagan, Israel) who tested for NEFA and IgG antibodies, respectively, in their laboratories. This research was partially funded by the Israel Marketing Board (Yehud, Israel).

\section{REFERENCES}

Adin, G., A. Gelman, R. Solomon, I. Flamenbaum, M. Nickbachat, E. Yosef. A. Zenou, A. Shamay, Y. Feuermann, S. J. Mabjeesh, and J. Miron. 2009. Effects of cooling dry cows under heat load conditions on mammary gland enzymatic activity, intake of food and water, and performance during the dry period and after parturition. Livest. Sci. 124:189-195.

Annen, E. L., R. J. Collier, M. A. McGuire, J. L. Vicini, J. M. Ballam, and M. J. Lormore. 2004. Effect of modified dry period lengths and bovine somatotropin on yield and composition of milk from dairy cows. J. Dairy Sci. 87:3746-3761.

Annen, E. L., A. C. Fitzgerald, P. C. Gentry, M. A. McGuire, A. V. Capuco, L. H. Baumgard, and R. J. Collier. 2007. Effect of continuous milking and bovine somatotropin supplementation on mammary epithelial cell turnover. J. Dairy Sci. 90:165-183.

Annen, E. L., M. A. McGuire, J. L. Vicini, and R. J. Collier. 2003. Effect of Posilac (bST) and dry period management strategy on milk yield. J. Dairy Sci. 86(Suppl. 1):154. (Abstr.)

Bachman, K. C., and M. L. Schairer. 2003. Bovine studies on optimal lengths of dry periods. J. Dairy Sci. 86:3027-3037.

Bernier-Dodier, P., C. L. Girard, B. G. Talbot, and P. Lacasse. 2011. Effect of dry period management on mammary gland function and its endocrine regulation in dairy cows. J. Dairy Sci. 94:4922-4936.

Bertics, S. J., R. R. Grummer, C. Cadorniga-Valino, and E. E. Stoddard. 1992. Effect of prepartum dry matter intake on liver triglyceride concentration and early lactation. J. Dairy Sci. 75:19141922 .

Butler, W. R., R. W. Everett, and C. E. Coppock. 1981. The relationships between energy balance, milk production and ovulation in postpartum Holstein cows. J. Anim. Sci. 53:742-748. 
Canfield, R. W., C. J. Sniffen, and W. R. Butler. 1990. Effects of excess degradable protein on postpartum reproduction and energy balance in dairy cattle. J. Dairy Sci. 73:2342-2349.

Capuco, A. V., S. E. Ellis, S. A. Hale, E. Long, R. A. Erdman, X. Zhao, and M. J. Paape. 2003. Lactation persistency: Insights from mammary cell proliferation studies. J. Anim. Sci. 81(Suppl. 3):18-31.

Collier, R. J., E. L. Annen-Dawson, and A. Pezeshki. 2012. Effects of continuous lactation and short dry periods on mammary function and animal health. Animal 6:403-414.

Darwash, A. O., G. E. Lamming, and J. A. Woolliams. 1997. The phenotypic association between the interval to post-partum ovulation and traditional measures of fertility in dairy cattle. Anim. Sci. 65:9-16.

Dirksen, G. U., G. H. Liebich, and E. Mayer. 1985. Adaptive changes of the ruminal mucosa and their functional and clinical significance. Bovine Pract. 20:116-120.

Ferguson, J. D., D. T. Galligan, and N. Thomson. 1994. Principal descriptors of body condition score in Holstein cows. J. Dairy Sci. $77: 2695-2703$

Grummer, R. R., and R. R. Rastani. 2004. Why reevaluate dry period length? J. Dairy Sci. 87(E-Suppl.):E77-E85.

Gulay, M. S., M. J. Hayen, K. C. Bachman, T. Belloso, M. Liboni, and H. H. Head. 2003. Milk production and feed intake of Holstein cows given short $(30 \mathrm{~d})$ or normal $(60 \mathrm{~d})$ dry periods. J. Dairy Sci. 86:2030-2038

Gümen, A., R. R. Rastani, R. R. Grummer, and M. C. Wiltbank. 2005. Reduced dry periods and varying prepartum diets alter postpartum ovulation and reproductive measures. J. Dairy Sci. 88:2401-2411.

Heuer, C., Y. H. Schukken, and P. Dobbelaar. 1999. Postpartum body condition score and results from the first test day milk as predictors of disease, fertility, yield, and culling in commercial dairy herds. J. Dairy Sci. 82:295-304.

Heuer, C., W. M. Van Straalen, Y. H. Schukken, A. Dirkzwager, and J. P. T. M. Noordhuizen. 2000. Prediction of energy balance in a high yielding dairy herd in early lactation: Model development and precision. Livest. Prod. Sci. 65:91-105.

Jolicoeur, M. S., A. F. Brito, D. Pellerin, D. Lefebvre, R. Berthiaume, and C. L. Girard. 2009. Short dry period management improves peripartum ruminal adaptation in dairy cows. J. Dairy Sci. 92(Suppl. 1):333. (Abstr.)

Klusmeyer, T. H., A. C. Fitzgerald, A. C. Fabellar, J. M. Ballam, R. A. Cady, and J. L. Vicini. 2009. Effect of recombinant bovine somatotropin and a shortened or no dry period on the performance of lactating dairy cows. J. Dairy Sci. 92:5503-5511.

Knight, C. H. 1998. Extended lactation. Pages 30-39 in Hannah Research Institute Yearbook 1998. E. Taylor, ed. Univ. Glasgow, UK.

Kuhn, M. T., J. L. Hutchison, and H. D. Norman. 2006. Effects of dry period length on yields of milk fat and protein, fertility and milk somatic cell score in the subsequent lactation of dairy cows. J. Dairy Res. 73:154-162.

Lotan, E., and J. H. Adler. 1976. Observations on the effect of shortening the dry period on milk yield, body weight, and circulating glucose and FFA levels in dairy cows. Tijdschr. Diergeneeskd. 101:77-82

Makuza, S. M., and B. T. McDaniel. 1996. Effects of days dry, previous days open, and current days open on milk yields of cows in Zimbabwe and North Carolina. J. Dairy Sci. 79:702-709.

NRC. 2001. Nutrient Requirements of Dairy Cattle. 7th rev. ed. Natl. Acad. Press, Washington, DC.
Pezeshki, A., J. Mehrzad, G. R. Ghorbani, H. R. Rahmani, R. J. Collier, and C. Burvenich. 2007. Effects of short dry periods on performance and metabolic status in Holstein dairy cows. J. Dairy Sci. 90:5531-5541.

Rastani, R. R., R. R. Grummer, S. J. Bertics, A. Gumen, M. C. Wiltbank, D. G. Mashek, and M. C. Schwab. 2005. Reducing dry period length to simplify feeding transition cows: Milk production, energy balance, and metabolic profiles. J. Dairy Sci. 88:1004-1014

Rémond, B., J. Kerouanton, and V. Brocard. 1997. The effect of reducing or omitting the dry period on the performance of dairy cows. INRA Prod. Anim. 10:301-315.

Rémond, B., A. Ollier, and G. Miranda. 1992. Milking of cows in late pregnancy-Milk production during this period and during the succeeding lactation. J. Dairy Res. 59:233-241.

Santschi, D. E., D. M. Lefebvre, R. I. Cue, C. L. Girard, and D. Pellerin. 2011a. Complete-lactation milk and component yields following a short (35-d) or conventional (60-d) dry period management in commercial Holstein herds. J. Dairy Sci. 94:2302-2311.

Santschi, D. E., D. M. Lefebvre, R. I. Cue, C. L. Girard, and D. Pellerin. 2011b. Incidence of metabolic disorders and reproductive performance following a short (35-d) or conventional (60-d) dry period management in commercial Holstein herds. J. Dairy Sci. 94:3322-3330. http://dx.doi.org/10.3168/jds.2010-3595.

SAS Institute. 2002. User's Guide: Statistics. Version 8. SAS Institute Inc., Cary, NC.

Smith, A., J. V. Wheelock, and F. H. Dodd. 1965. Effect of milking throughout pregnancy on milk yield in the succeeding lactation. J. Dairy Sci. 49:895-896.

Sørensen, J. T., and C. Enevoldsen. 1991. Effect of dry period length on milk production in subsequent lactation. J. Dairy Sci. 74:1277-1283.

Staples, C. R., W. W. Thatcher, and J. H. Clark. 1990. Relationship between ovarian activity and energy status during the early postpartum period of high producing dairy cows. J. Dairy Sci. 73:938-947.

Stevenson, J. S., M. K. Smith, and E. P. Call. 1983. Factors affecting reproductive performance of dairy cows first inseminated after five weeks postpartum. J. Dairy Sci. 66:1148-1154.

Thatcher, W. W., and C. J. Wilcox. 1973. Postpartum estrus as an indicator of reproductive status in dairy cows. J. Dairy Sci. $56: 608-610$.

Velasco, J. M., E. D. Reid, K. K. Fried, T. F. Gressley, R. L. Wallace, and G. E. Dahl. 2008. Short-day photoperiod increases milk yield in cows with a reduced dry period length. J. Dairy Sci. 91:3467-3473.

Watters, R. D., J. N. Guenther, A. E. Brickner, R. R. Rastani, P. M. Crump, P. W. Clark, and R. R. Grummer. 2008. Effects of dry period length on milk production and health of dairy cattle. J. Dairy Sci. 91:2595-2603.

Watters, R. D., M. C. Wiltbank, J. N. Guenther, A. E. Brickner, R. R. Rastani, P. M. Fricke, and R. R. Grummer. 2009. Effect of dry period length on reproduction during the subsequent lactation. J. Dairy Sci. 92:3081-3090.

Zachut, M., A. Arieli, H. Lehrer, L. Livshitz, S. Yakoby, and U. Moallem. 2010. Effects of increased supplementation of n-3 fatty acids to transition dairy cows on performance and fatty acid profile in plasma, adipose tissue, and milk fat. J. Dairy Sci. 93:5877-5889. 